\title{
A importância do lúdico para a criança
}

\author{
Lúcia Eugenia Pittas Martini
}

Com licenciatura em Pedagogia, é docente universitária de Currículos e Programas e de Metodologia do Ensino de 1ํ Grau, coordenadora pedagógica da rede estadual, em Dourados-MS, e mestranda do Programa de Mestrado em Educaçāo da UCDB.

Observando as crianças nestes muitos anos, trabalhando como professora, coordenadora e como mãe, tenho comprovado o quanto a brincadeira é parte integrante de suas vidas. Comparando o comportamento de alunos em sala de aula e durante as atividades recreativas ou no recreio, percebe-se uma grande diferença. Lá estão inquietas, distraídas, contidas, forçadas até. Soltas, livres das quatro paredes da "prisão", correm, pulam, riem, gritam, o ambiente se transforma, tudo é motivo para diversão.

O que é brincadeira na vida da criança? Apenas um passatempo? Diversão? Momento para descobertas? Para a criação? Instantes de liberdade e de prazer? Ou necessidade?

Refletindo sobre estas indagaçōes e outras é que nos propusemos à elaboração deste trabalho. Porque, quando observamos os jogos e as brincadeiras infantis, vem-nos a certeza de que para as crianças a brincadeira é coisa séria.

Por isso, detestam serem interrompidas. Quando isto acontece, geralmente rea- gem, ignorando a interrupção, às vezes ficam irritadas, até mesmo agressivas.

Se nós educadores quisermos conhecer o sentido do lúdico para as crianças, precisamos observá-lo a partir do ponto de vista delas, pois a brincadeira é uma das atividades mais importantes para a relação afetiva e cognitiva com objetivos e conceitos que as cercam.

Cabem aqui alguns conceitos, conforme Friedmann (1992 : 24):

Brincadeira: refere-se basicamente à ação de brincar, ao comportamento espontâneo que resulta de uma atividade não estruturada. Jogo: trata-se de uma brincadeira que envolve regras. Brinquedo: refere-se ao objeto de brincar. Atividades lúdicas: abrangem de forma mais ampla os conceitos anteriores. Lúdico: termo criado por Flournay para servir como adjetivo correspondente à palavra jogo.

Por que brincar? É Cunha (1992: 35) quem responde:

Porque brincar é essencial à saúde física, emocional e intelectual do ser humano. Brincar é coisa séria também, porque na brincadeira não há trapaça, há sincerida- 
de, engajamento voluntário e doaçāo. Brincando nos reequilibramos, reciclamos nossas emoçōes e nossa necessidade de conhecer e reinventar. E tudo isso desenvolvendo atenção, concentração e muitas outras habilidades.

Das brincadeiras mais freqüentes que a criança utiliza para construir seu conhecimento destaca-se o jogo, pela sua importância. Devido a um conceito generalizado de que nas situaçōes em que a criança atua através de jogos ou brincadeiras, não está fazendo ou aprendendo nada, a escola formal faz muito pouco uso destas estratégias.

Dentre os autores estudados, Lima (1998 : 48) caracteriza de forma adequada esta separação:

Tem-se, assim, historicamente formada, uma cisão entre o lúdico e o pedagógico, entre o que é brincadeira e o que é estudo sério. Isso do nosso ponto de vista de adulto, porque para a criança o brincar é sempre uma coisa séria na medida em que mobiliza suas possibilidades intelectuais e afetivas com um fim determinado.

Segundo Almeida (1987 : 26):

O brinquedo faz parte da vida da criança. Ele simboliza a relação pensamento-ação e, sob este ponto, constitui provavelmente a matriz de toda a atividade lingüística, ao tornar possível o uso da fala, do pensamento e da imaginação.

Brincando com seu corpo, nos primeiros meses de vida, a criança inicia sua primeira relação com o mundo. Movimenta seus pés, mãos e dedos; pega objetos manipulando-os, joga-os no chão, ouve o barulho, repete o gesto se alguém "entra na brincadeira" e lhe devolve o objeto. Iniciase aí a interação entre o brinquedo e a criança, processo que continuará por toda a vida.

Este processo envolve não apenas o brincar por brincar, mas é bem mais complexo: inclui o apego, a imitação, a representação que favorecem a vontade de crescer, de se desenvolver. Ao brincar com bonecas ou objetos domésticos, a criança se exercita e ao mesmo tempo reproduz através dos mesmos suas relaçōes e conflitos. Se existem sentimentos de culpa, grita e gesticula como a mãe ou, se tem necessidade de afeto, trata com afeto e carinho. Utiliza-se do brinquedo para a representação, ocorrendo então uma forma de pensamento.

Para Benjamin (1984 : 69), a função do brinquedo ultrapassa os limites técnicos chegando a uma significação mais profunda, filosófica e psicológica. Isto porque não se chegaria à realidade ou ao conceito de brinquedo, explicando unicamente pela visão da criança ou pela concepção de adulto, mas sim através do estudo do povo, da classe de que provém o brinquedo, testemunho do diálogo mudo e simbólico entre ele e sua gente.

Subjacente está a conotação "política" que a sociedade oferece hoje, para a criança, o que ela deseja amanhã. A posição de Ariès (1978 : 113) é a de:

que em torno dos divertimentos mais naturais, com significado projetivo, como utilização de brinquedos, bonecos, soldadinhos, armas, rodas, que apareciam e desapareciam no decorrer das épocas, representava-se o tipo de valores e concepçōes que se desejava passar e incutir nas crianças e adolescentes (...) Os brinquedos atuais variam entre brados de guerra, morte, combates, prazer, consu- 
mo, utilizados pelas crianças, passando pelos jogos eletrônicos utilizados pelos adolescentes e atingindo os brinquedos de sex-shopping e jogos nas estrelas utilizados pelos adultos. Neles todos está imbuído o desejo de destruir, alienar e consumir.

Até que ponto os pais e educadores estão cientes e conscientes desta conotação? Resgatar os brinquedos simples próprios da tradição cultural do povo deve ser tarefa dos educadores, principalmente dos que trabalham com crianças da pré-escola e das séries iniciais.

A criança inicia sua integração social através do brinquedo, aprende a viver com os que a cercam, situa-se frente ao mundo. Sua preferência e atenção voltamse, principalmente, para caixas de papelāo, papéis coloridos, tampas de panelas - "sucatas" - mais atraentes, pela textura, baruIho, som e gosto, do que objetos "fabricados" para ela.

Aos poucos passa para a fase do jogo simbólico quando cria regras e puniçōes, onde o brinquedo representa parte do universo já conhecido. Observando uma criança brincar, o adulto pode conhecê-la e ao seu estado de espírito, pois através do brinquedo a criança desenvolve seu lado emocional e afetivo, além de algumas áreas do domínio cognitivo, principalmente a capacidade de análise e síntese, bem como o jogo simbólico.

O brinquedo também tem um aspecto mágico. Para Weiss (1989 : 25):

este é mais difícil de ser analisado. Não sabemos responder com precisão por alguns brinquedos nos fascinam e até nos remetem à esfera de lembranças remo- tas, sensaçōes e emoçōes engavetadas em algum canto da nossa memória. Imagens ancestrais, arquetípicas, que transformam brinquedos em quaseritos: uma roda barulhenta, uma bola murcha, um barquinho de papel flutuando na água, uma pipa molhada pela garoa, um balāozinho de papel flutuando pelo ar; são brinquedos-lembranças eternos sempre atuais.

Este mundo do faz-de-conta, onde qualquer objeto toma formas variadas dependendo da imaginação, faz a criança ter domínio sobre a situação real, transformando a casa dos pais na sua casa, seu castelo, sua floresta, ocorrendo então uma integração plena do lúdico, em que brincar e aprender ocorrem concomitantemente.

Para muitos pais e educadores deve haver uma separação entre a hora de brincar e hora de aprender. Para Weiss (1989: 26), faz-se dicotomia entre lazer/trabalho, entre brincar/estudar, fragmentação reforçada pela escola e continuada em casa, enfatizam-se os conceitos de que brincar é prazeroso, trabalhar - numa sociedade competitiva - é uma atividade superior, brincar não rende dinheiro, não é lucrativo, ao passo que trabalhar significa competir, sobreviver, ter "poder". A brincadeira passa a significar uma recompensa após o estudo, após o trabalho. Após esta introjeção cultural, o adulto passa a ter dificuldade em aceitar o prazer, até no próprio trabalho, desenvolvendo processo de culpa em relação ao ócio, ao "não-fazer-nada". A própria escola enfatiza esta visão ao desconsiderar aula de recreação, artes, música, teatro, etc... Não podemos esquecer que o brinquedo estimula funções importantes como o pensamento criativo e o desenvolvimento social e emocional. 
É preciso atentar também para a indústria de brinquedos que oferece tantos e tão variados modelos, auxiliada pelos meios de divulgação, pondo à disposição de todos, adultos e crianças, às vezes de maneira pouco honesta, brinquedos atrativos aos olhos, nem sempre educativos, dificilmente criativos, onde o usuário, quase sempre, só aperta botões, tornando a criança passiva, apenas observadora. São mecanismos de causalidade adulta, já vêm prontos, a criança só os utiliza, não há caminhos a percorrer, não há nada para imaginar. Parado o mecanismo, o brinquedo deixa de interessar, fica de lado ou é desmontado para "ver" o que tem lá dentro.

O brinquedo tem uma conformação coletiva, bem caracterizada em atividades realizadas em quintais, ruas, parques: as bolinhas de gude, a amarelinha, os jogos de bola são exemplos típicos de atividades lúdicas sociais. Mas estes jogos tendem a desaparecer, pois o ambiente urbano é hostil à criança, principalmente nos grandes centros. Vão sendo substituídos por jogos mais passivos ou solitários: videogames, filmes e programas de TV. Alguns brinquedos tradicionais também estão sendo abandonados pois exigem a presença de pais e avós para a sua organização e estes já não dispõem de tempo para brincar com seus fiIhos e netos. Surge uma dúvida quanto à questão fundamental do lúdico: como resgatar do ato de brincar a sua atividade prazerosa, criativa, espontânea?

Segundo Piaget (apud FRIEDMAN, 1992 : 173), a criança tem, inicialmente, uma inteligência sensório-motriz, somente perceber não basta para ela compreender e assimilar as coisas: ela precisa agir. É para atender a esta necessidade que a criança busca sempre uma atividade "lúdica". "Jogar é pensar" diz Piaget. É através do jogo que a criança descobre e compreende meIhor o mundo que a cerca. E é de Piaget a classificação de jogos, relacionada com estágios evolutivos do pensamento infantil: a) de exercícios - forma mais primitiva de jogo, não comporta simbolismo e nem técnica lúdica; b) simbólicos - são os jogos de "faz-de-conta", implicam a representação de significaçōes e são indispensáveis ao equilíbrio afetivo e intelectual da criança, permitindo a ela reavivar suas alegrias, conflitos, medos, resolvendo-os à sua maneira; c) de regras - são transmitidos socialmente de criança para criança e são tão mais importantes quanto suas regras são aceitas e compreendidas - a criança está apta a estabelecer relações sociais e interindividuais. É através destas formas de jogo que a criança desenvolve condutas de manifestação de função simbólica que não pode ser formalizada na linguagem oral. 0 jogo, o brinquedo, é o complemento das palavras.

A família tem a função fundamental no desenvolvimento da criança. Para Almeida (1987 : 31):

Falar, ler, contar histórias, conversar, brincar, correr, montar a cavalo, ler para os filhos, possibilitar estimulaçōes variadas, participar são atitudes que educam a criança, levando-a a alcançar uma mente ativa, um corpo saudável e um estado emocional de equilíbrio. Uma criança consegue distinguir um tratamento afetuoso e estimulante de um tratamento hostil e de desamor apresentado pelo adulto - e por sinal, consegue emitir uma resposta de apro- 
ximação ou afastamento. É exatamente este contato afetuoso e estimulante do adulto com a criança que caracteriza o primeiro sinal de uma verdadeira educação lúdica.

É justamente esta educação lúdica que precisamos implantar nas escolas. Para que isto se efetive, é preciso divulgar os estudos realizados na área para que o educador tome conhecimento da importância e da necessidade do lúdico para o desenvolvimento da criança, pois através do brincar ela irá sentir prazer, sem culpa, desenvolver o social e o emocional e principalmente evoluir no cognitivo, razão primeira da escola.

A criança vai à escola para receber a transmissão formal de conhecimentos, na qual o professor é uma das grandes fontes na forma de ensinar. Mas a criança também aprende, na interação com as outras crianças. Para Lima (1988 : 53):

A transmissão oral e conhecimentos é uma das formas de ensinar; a experimentação direta, a observação dos fatos, a discussão das observações, a troca de informações, atividades lúdicas são outras.

Se a criança aprende brincando, então a escola deve fazer a integração do ato lúdico, juntar o aprender e o brincar, fazendo da escola um local de risos, alegrias e do ato de aprender uma brincadeira, uma atividade criativa e prazerosa.

\section{Bibliografia}

ALMEIDA, Paulo Nunes. Educação lúdica: técnicas e jogos pedagógicos. 5.ed. São Paulo: Loyola, 1987.

ARIĖS, Philippe. História social da criança e da família. Rio de Janeiro: Guanabara, 1978.

FRIEDMAN, Adriana et al. O direito de brincar: brinquedoteca. São Paulo: Scritta, 1992.

KISHIMOTO, Tizuko M. Jogos tradicionais infantis. Petrópolis: Vozes, 1993.

LEBOVICl, S.; DIATKINE, R. Significado e função do brinquedo na criança. 3.ed. Trad. Liana di Marco. Porto Alegre: Artes Médicas, 1985.

SECRETARIA DE ESTADO DA EDUCAÇĀO E CULTURA - RS. Função simbólica. Porto Alegre: SEEC, 1986. (Série pré-escolar).

SECRETARIA DE ESTADO DA EDUCAÇĀO E CULTURA - SP. Ciclo básico em jornada única: uma nova concepção de trabalho pedagógico. São Paulo: SEEC, 1988.

SEBER, Maria da Glória. Construção da inteligência pela criança: atividades do período preparatório. São Paulo: Scipcione, 1989. (Série: Pensamento e Ação no Magistério).

VAYER, Pierre et al. Linguagem corporal. a estrutura e a sociologia da ação. Trad. Bernardina M. de Albuquerque. Porto Alegre: Artes Médicas, 1985.

WEISS, Luise. Brinquedos dengenhocas: atividades lúdicas com sucata. São Paulo: Scipione, 1989. (Série Pensamento e Ação no Magistério). 
